\title{
MASTER k-1699
}

THE TUNGSTEN HEXAFLUORIDE-HYDROGEN FLUORIDE TRIPLE POINT CURVE AND ITS APPLICATION TO A METHOD OF ANALYSIS

AUTHOR:

W. D. Hedge

\section{UNION} CARBIDE

\section{UNION CARBIDE CORPORATION} NUCLEAR DIVISION
- OAK RIDGE NATIONAL LABORATORY

- PADUCAH GASEOUS DIFFUSION PLANT 


\section{DISCLAIMER}

This report was prepared as an account of work sponsored by an agency of the United States Government. Neither the United States Government nor any agency Thereof, nor any of their employees, makes any warranty, express or implied, or assumes any legal liability or responsibility for the accuracy, completeness, or usefulness of any information, apparatus, product, or process disclosed, or represents that its use would not infringe privately owned rights. Reference herein to any specific commercial product, process, or service by trade name, trademark, manufacturer, or otherwise does not necessarily constitute or imply its endorsement, recommendation, or favoring by the United States Government or any agency thereof. The views and opinions of authors expressed herein do not necessarily state or reflect those of the United States Government or any agency thereof. 


\section{DISCLAIMER}

Portions of this document may be illegible in electronic image products. Images are produced from the best available original document. 
Printed in the United States of America. Available from Clearinghouse for Federal Scientific and Techniral Informatiun, National Bureau of Standards,

U.S. Department of Commerce. Soringfiald, Virginiu 22151

Price: Printed Cupy $\$ 3.00$; Microfiche $\$ 0.65$

\section{LEGAL NOTICE}

This report was prepared as an account of Government sponsored work. Neither the United States, nor the Commission, nor any person acting on behalf of the Commission:

A. Makes any warranty or representation, expressed or implied, with respect to the accuracy, completeness, or usefulness of the information contained in this report, or that the use of any information, apparatus, method, or process disclosed in this report may not infringe privately owned rights; or

B. Assumes any liabilities with respect to the use of, or for damages resulting from the use of any information, apparatus, method, or process disclosed in thire report.

$\Lambda_{g}$ used in lie above, "person acting on behalf of the Commission" includes any employee or contractor of the Commission, or employee of such contractor, to the extent that such employee or contractor of the Commission, or employee of such contractor prepares, disseminates, or provides access to, any information pursuant to his employment or contract with the Commission, or his employment with such contractor. 
THE TUNGSTEN HEXAFLUORIDE-HYDROGEN FLUORIDE TRIPLE POINT CURVE AND ITS APPLICATION TO A METHOD OF ANALYSIS

W. D. Hedge

Technical Division

UNION CARBIDE CORPORATION

NUCIEAR DIVISION

Oak Ridge Gaseous Diffusion Plant

Oak Ridge, Tennessee.

(

\section{LEGAL NOTICE}

as an account of Governits

A. Make Commission, nor any person acilng on bonsored work. Neither the Uniter racy, completeness, orsanty or representation, exprosoct wil of the Commisston:

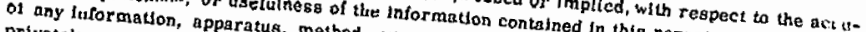

vately ouned rights: or method, or process diselosed in this report, or that the is-

B. Assumes any: or

uae of any informatson lities with ncspect to the use of or for ding

As used in the apparatis, methul, nr procese of, or for drmayes rasuting tror-

ployee nr contractor of the Dereen anting on buthall of the com this report.

guen employee or contrictor or ission, or employee of such contaston" includes any et

disseminates, or provites at the commiselon, or employes contractor, to the extent tha

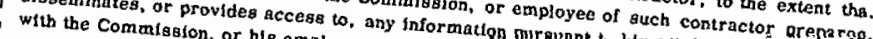

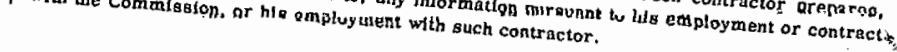




\section{THIS PAGE \\ WAS INTENTIONALLY \\ LEFT BLANK}


Report Number: K-1699

Subject Category: CHEMISTRY

Title: THE TUNGSTEN HEXAFLUORIDEHYDROGEN FLUORIDE TR:IPLE POINT CURVE AND ITS APPLICATION TO A METHOD OF ANALYSES

Author: W. D. Hedge

\section{A B S T R A C T}

The triple point curve for the binary system tungsten hexafluoridehydrogen fluoride has been determined over the range of 0.0 to 6.0 mole percent hydrogen fluoride. This system is represented by the following equation:

$$
\text { Mole Fraction } \mathrm{HF}=(\Delta t)^{2} \mathrm{e}^{-3.65}
$$

where $\Delta t$ is the depression of the triple point of pure tungsten hexafluoride in degrees centigrade.

A method is presented for correcting the deviations resulting from nonideality of the binary system. Extensions of the observed triple point depressions of different ratios of liquid volume to total volume are represented by the following equation:

$$
\text { Mole Fraction } \mathrm{HF}=(\Delta \mathrm{t})^{2} \exp \left(-4.15+1.1 \mathrm{IR}-0.61 \mathrm{R}^{2}\right)
$$

where $\Delta t$ is defined above and $R$ is the ratio of liquid volume to total volume. 
THIS PAGE

WAS INTENTIONALLY

LEFT BLANK 
THE TUNGSTEN HEXAFLUORIDE-HYDROGEN FLUORIDE TRIPLE POINT CURVE AND ITS APPLICATION TO A METHOD OF ANALYSIS

A nondestructive analytical method was needed to measure the purity of tungsten hexafluoride. Since hydrogen fluoride is the major impurity encountered in this laboratory, cryoscopic analysis appears to be the most promising. Preliminary calculations from the heat of fusion of tungsten hexafluoride (1) indicate that the molal freezing (triple) point constant is $106.7^{\circ} \mathrm{C}$ per mole of hydrogen fluoride per 1000 grams of tungsten hexafluoride. The purpose of this study is to provide a method of analysis for hydrogen fluoride in a binary solution with tungsten hexafluoride.

\section{SUMMARY}

The triple point curve for the binary system tungsten hexafluoridehydrogen fluoride has been determined over the range of 0.0 to 6.0 mole percent hydrogen fluoride. This system is represented by the following equation:

$$
\text { Mole Fraction } \mathrm{HF}=(\Delta t)^{2} e^{-3.65}
$$

where $\Delta t$ is the depression of the triple point of pure tungsten hexafluoride in degrees centigrade.

A method is presented for correcting the deviations resulting from nonideality of the binary system. Extensions of the observed triple point depressions of different ratios of liquid volume to total volume are represented by the following equation:

$$
\text { Mole Fraction } \mathrm{HF}=(\Delta t)^{2} \exp \left(-4.15+1.11 \mathrm{R}-0.61 \mathrm{R}^{2}\right) \quad \text { (Equation 2) }
$$

where $\Delta t$ is defined above and $R$ is the ratio of liquid volume to total volume.

\section{EQUI PMENT}

\section{Apparatus}

A $50 \mathrm{ml}$ triple point cell (figure 1) was used to contain the solution. It was a Monel cylinder, 4-1/2 inches long and 1-5/16 inches in diameter, with a small Hoke valve silver-soldered near the top. A 3/8-inch-diameter thermowell extended through the top of the cylinder to within $1 / 2$ inch of the bottom. The top half of the thermowell was made of Monel and the bottom half was made of copper tubing. The thermowell was closed inside the cell with a 3/8-inch copper cap.

A calibrated gas pipette (figure 2) was used to dilute the tungsten hexafluoride with milligram quantities of hydrogen fluoride. The one liter 


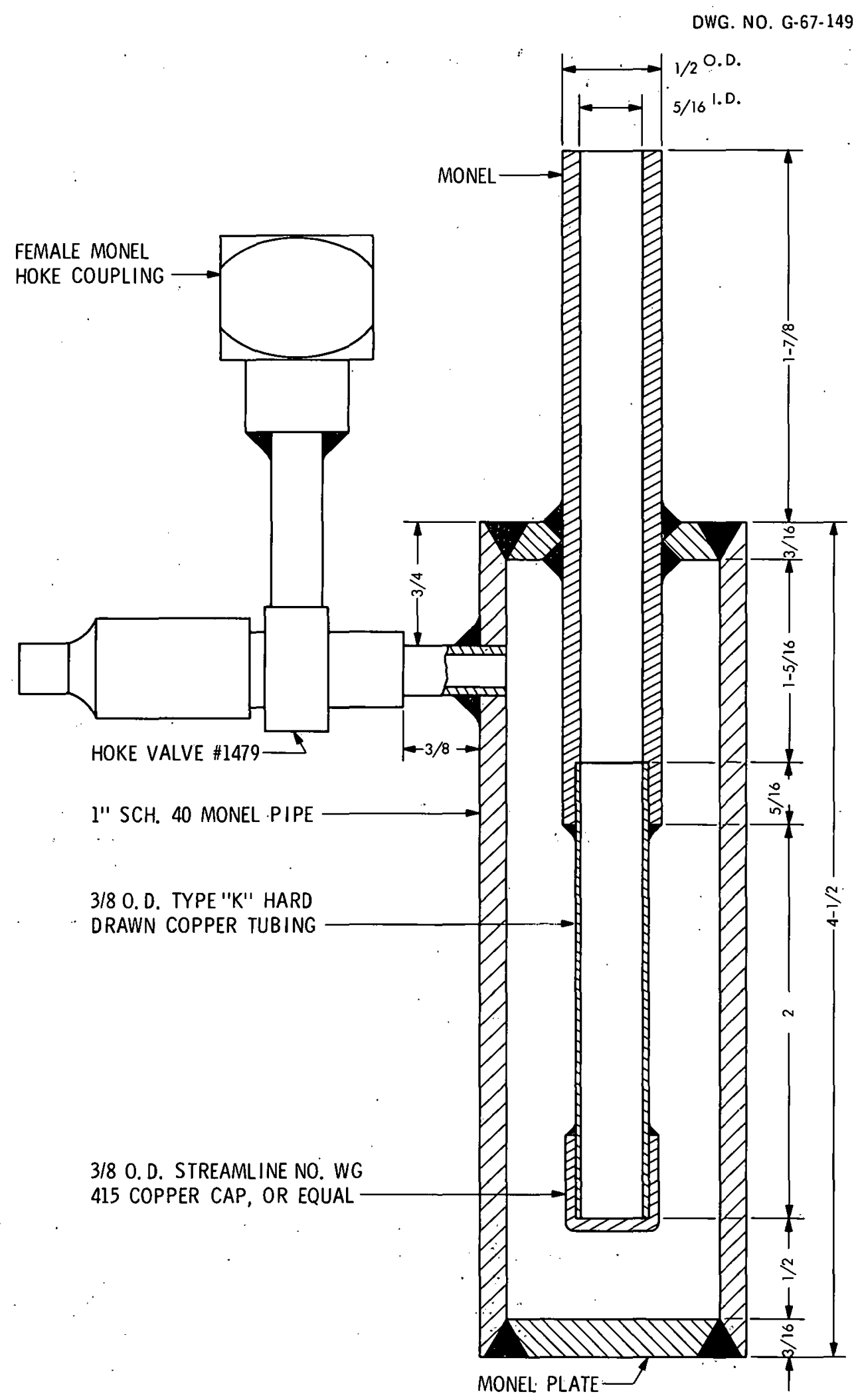

Figure 1

TRIPLE POINT CELL 
DWG. NO. G-67-165

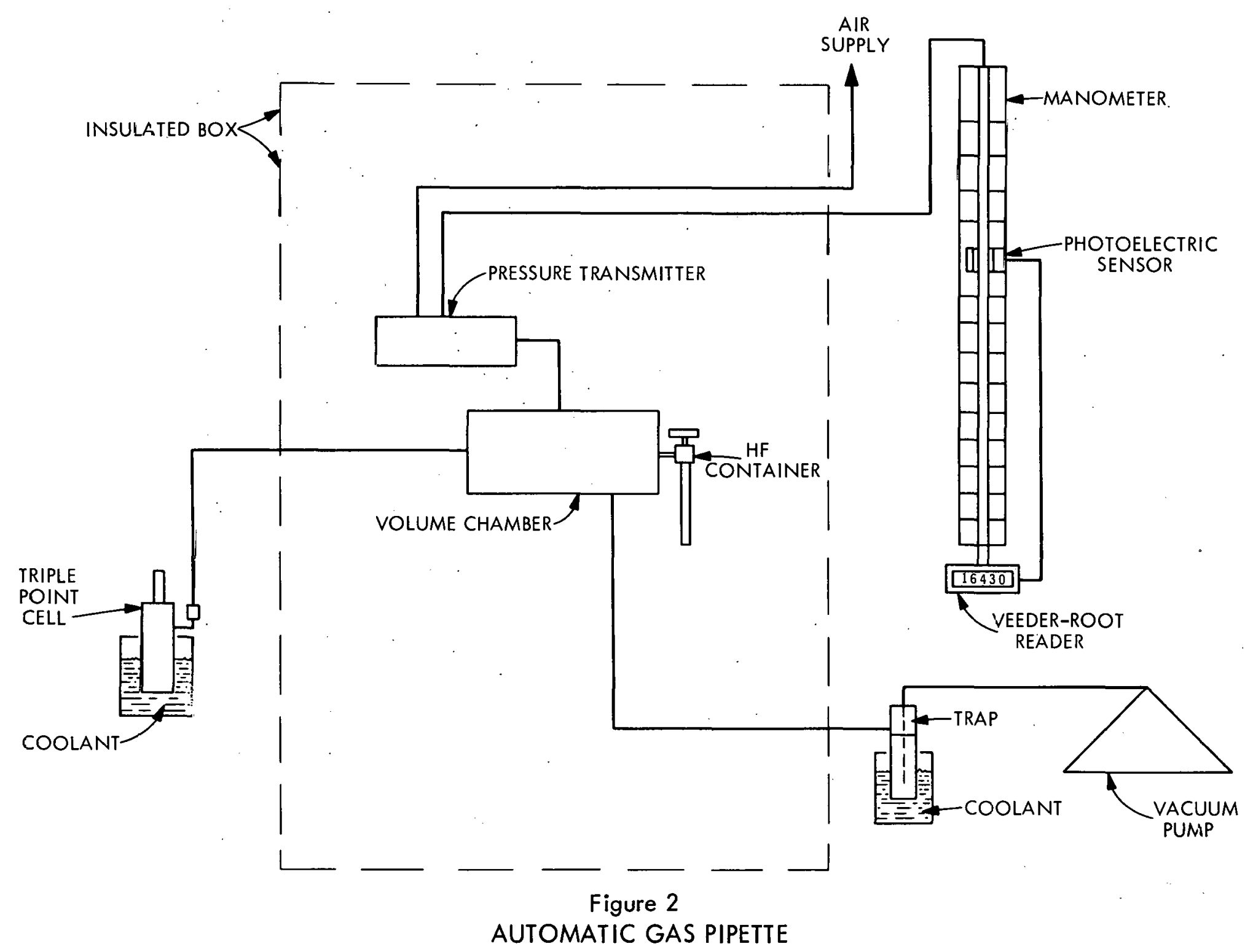


pipette was made of Monel with copper transfer lines. Pneumatic valves with neoprene gaskets were used in the transfer lines. The pressure was read from an automatic manometer with a digital Veeder-Root reader in conjunction with a 50 millimeter pressure transmitter. An insulated box, maintained at $104^{\circ} \mathrm{C}$, enclosed the volume chamber, valves, transmitter, hydrogen fluoride container, and all transfer lines (except the output line). The pipetted hydrogen fluoride was condensed into the $50 \mathrm{ml}$ triple point cells at liquid nitrogen temperature (about $-190^{\circ} \mathrm{C}$ ).

The triple point bath was a stainless steel container enclosed in about an inch of Styrofoam with a split Styrofoam cover. The bath solution, a l:I mixture of isopropyl alcohol and water, was maintained at about $0.3{ }^{\circ} \mathrm{C}$ below the expected triple point. A thyratron control panel was used to control a variable speed circulating pump. The thyratron tube was activated by temperature changes of $\pm 0.05^{\circ} \mathrm{C}$ sensed with a thermistor inserted in the bath. A vernier was used to set the desired bath temperature. A motor-driven propeller, manually controlled by a transformer, circulated the bath solution (figure 3 ).

Temperature measurements were obtained using a ten-junction, copperconstantan thermocouple that was calibrated against a certified platinum resistance thermometer. Ice made from distilled water was used as the reference junction for the thermocouple. The emf produced was measured on a Leeds and Northrup potentiometer using an Electronik null point indicator. A standard calomel cell was used as a reference for the bridge circuit of the potentiometer.

Mater1als

To separate the tungsten hexafluoride from nonvolatile material, the tungsten hexafluoride was successively distilled into receiving traps at $-25^{\circ} \mathrm{C}$. Continuous vacuum pumping on the traps removed noncondensable matter. The condensed tungsten hexafluoride was sampled and a triple point of $1.96 \pm 0.05^{\circ} \mathrm{C}$ was obtained, indicating no significant difference from the $2^{\circ} \mathrm{C}$ triple point of pure tungsten hexafluoride (2). Infrared and mass spectrometer scans of the purified material revealed no detectable impurities. A molal freezing (triple) point constant of $19.3^{\circ} \mathrm{C}$ per mole of tungsten hexafluoride per 1000 grams of uranium hexafluoride, compared to the established constant of $19.2 \pm 0.7^{\circ} \mathrm{C}$ (3), was obtained, which indicated pure tungsten hexafluoride.

Anhydrous hydrogen fluoride was prepared by selective sorption on sodium fluoride pellets.

\section{EXPERTMENTAL AND PROCEDURE}

Preparing the Solutions

The triple point of the tungsten hexafluoride in each of the triple point cells was measured to confirm the purity of the solvent. The individual triple point cells contained the following quantities of tungsten hexafluoride: FP-29 contained 46.83 grams; FP-49, 92.91 grams; and FP-42, 
DWG. NO. G-67-150

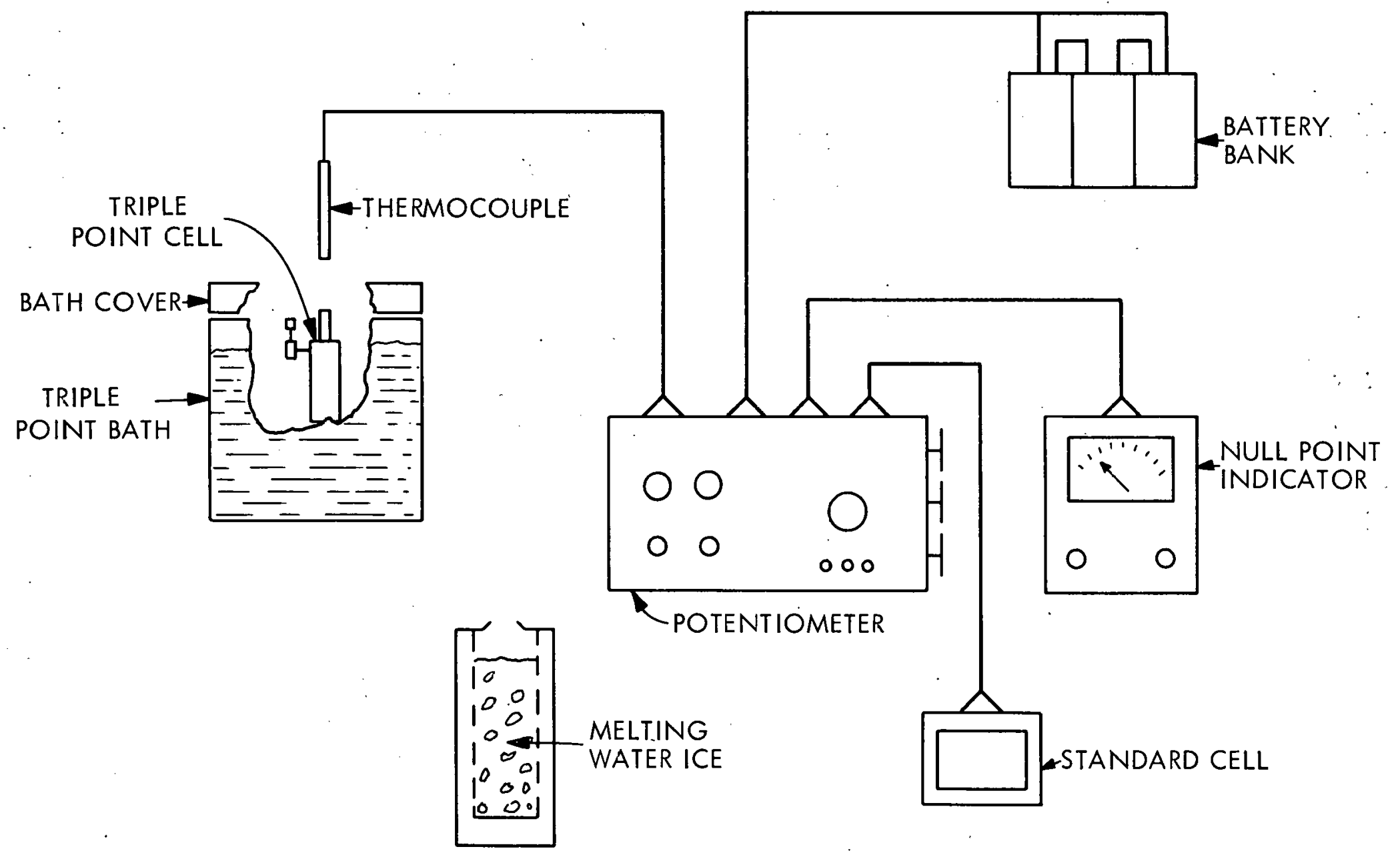

Figure 3

TRIPLE POINT MEASUREMENT ASSEMBLY 
130.1l grams. Each cell was individually attached to the fitting on the outlet line of the gas pipette and cooled to about $-190^{\circ} \mathrm{C}$ with liquid nitrogen. The pipette chamber and transfer lines were evacuated to less than $50 \times 10^{-3}$ torr. Hydrogen fluoride was then introduced to the isolated pipette chamber to the desired pressure, and subsequently condensed into the triple point cell. The quantity of the condensed hydrogen fluoride was calculated from the pressure change and known volume of the pipette. The procedure was followed for each data point.

Measuring the Triple Points

Two $\mathrm{ml}$ of bath solution were placed in the thermowell of the triple point cell to act as the heat transfer agent between the thermowell and the thermocouple. The triple point cell was placed in the constant temperature cooling bath previously adjusted to a temperature slightly (about $0.3^{\circ} \mathrm{C}$ ) below the expected triple point. The cooling curve was followed as the temperature decreased. When the tungsten hexafluoride solution supercooled, the cell was tapped to start crystallization. Figure 4 is a representative triple point curve obtained in this manner.

$\underline{\text { Data }}$

Table I contains the following data per point for cells FP-29, FP-49, and FP-42: the cumulative grams of hydrogen fluoride added to the triple point cells, the cumulative weight percent and mole fractions of hydrogen fluoride in the triple point cells, the triple point depression $(\Delta t)$, the confidence limit of the temperature measurement, and the number of determinations made per point. The data was fitted to a general parabolic least squares equation on an IBM 7090 computer and the equations in Table II obtained.

Figure 5 is a plot of the mole fractions of hydrogen fluoride in tungsten hexafluoride $\left(M_{f}\right)$ versus the triple point depression $(\Delta t)$ as calculated from the equations in Table II. 
DWG. NO. G-67-151

j

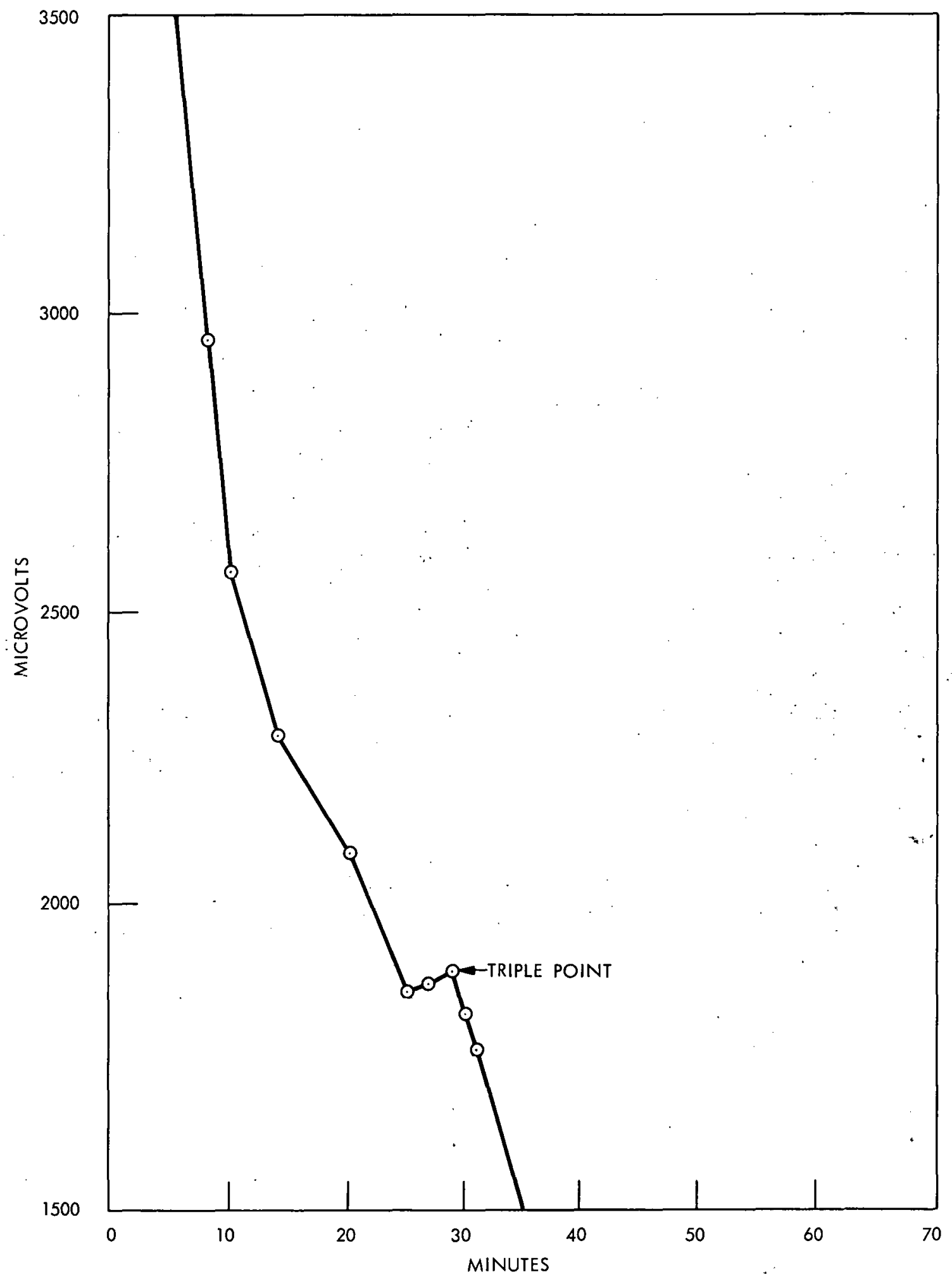

Figure 4

TYPICAL TRIPLE POINT CURVE 
TABLE I

TRIPLE POINT LOWERING OF TUNGSTEN HEXAFLUORIDE WITH HYDROGEN FLUORIDE

\begin{tabular}{|c|c|c|c|c|c|c|c|c|}
\hline Cylinder & $\begin{array}{l}\text { Net Weight } \\
\mathrm{WF}_{6}, \mathrm{~g} \\
\end{array}$ & Ratio* & $\begin{array}{l}\text { Cumulative } \\
\text { Weight of } \\
\text { HF, g } \\
\end{array}$ & $\begin{array}{c}\text { Cumulative } \\
\text { Weight } \\
\text { Percent HF } \\
\end{array}$ & $\begin{array}{l}\text { Cumulative } \\
\text { Mole } \\
\text { Fractions HF } \\
\end{array}$ & $\Delta t\left({ }^{\circ} \mathrm{C}\right)$ & $95 \%$ C.L. & $\begin{array}{c}\text { Number of } \\
\text { Triple Point } \\
\text { Determinations } \\
\end{array}$ \\
\hline \multirow[t]{7}{*}{ FP-29 } & 46.83 & 0.266 & 0.0000 & 0.0000 & 0.00000 & 0.000 & \pm 0.029 & 7 \\
\hline & & & 0.0262 & 0.0559 & 0.00497 & 0.457 & \pm 0.027 & 7 \\
\hline & & & 0.0737 & 0.1571 & 0.01726 & 0.941 & \pm 0.024 & 7 \\
\hline & & & 0.1171 & 0.2494 & 0.02819 & 1.162 & \pm 0.018 & 9 \\
\hline & & & 0.1676 & 0.3566 & 0.04065 & 1.452 & \pm 0.035 & 8 \\
\hline & & & 0.2007 & 0.4360 & 0.04863 & 1.604 & \pm 0.024 & 9 \\
\hline & & & 0.2371 & 0.5038 & 0.05725 & 1.589 & \pm 0.007 & 7 \\
\hline \multirow[t]{8}{*}{ FP-49 } & 92.91 & 0.528 & 0.0000 & 0.0000 & 0.00000 & 0.000 & \pm 0.020 & 7 \\
\hline & & & 0.0325 & 0.0350 & 0.00428 & 0.428 & \pm 0.023 & 7 \\
\hline & & & 0.1304 & 0.1402 & 0.01707 & 0.860 & \pm 0.015 & 7 \\
\hline & & & 0.2235 & 0.2400 & 0.02890 & 1.091 & \pm 0.011 & 8 \\
\hline & & & 0.3559 & 0.3816 & 0.04523 & 1.351 & \pm 0.013 & 7 \\
\hline & & & 0.5441 & 0.5822 & 0.06750 & 1.412 & \pm 0.012 & 8 \\
\hline & & & 0.8249 & 0.8801 & 0.09895 & 1.468 & \pm 0.013 & 7 \\
\hline & & & 1.0964 & 1.1663 & 0.12736 & 1.494 & \pm 0.008 & 7 \\
\hline \multirow[t]{8}{*}{ FP-42 } & 130.11 & 0.738 & 0.0000 & 0.0000 & 0.00000 & 0.000 & \pm 0.041 & 6 \\
\hline & & & 0.0500 & 0.0384 & 0.00473 & 0.432 & \pm 0.029 & 7 \\
\hline & & & 0.1889 & 0.1450 & 0.01765 & 0.869 & \pm 0.033 & 7 \\
\hline & & & 0.3310 & 0.2538 & 0.03050 & 1.067 & \pm 0.028 & 8 \\
\hline & & & 0.4905 & 0.3756 & 0.04464 & 1.167 & \pm 0.011 & 7 \\
\hline & & & 0.7689 & 0.5875 & 0.06819 & 1.248 & \pm 0.008 & 8 \\
\hline & & & 0.9753 & 0.7440 & 0.08491 & 1.282 & \pm 0.014 & 7 \\
\hline & & & 1.3393 & 1.0189 & 0.13294 & 1.269 & \pm 0.008 & 7 \\
\hline * Ratic & iquid & & al Volu & & & & & \\
\hline
\end{tabular}


TABLE II

LEAST SQUARES EQUATIONS FROM THE THREE TRIPLE POINT CURVES OF HYDROGEN FLUORIDE IN TUNGSTEN HEXAFLUORIDE

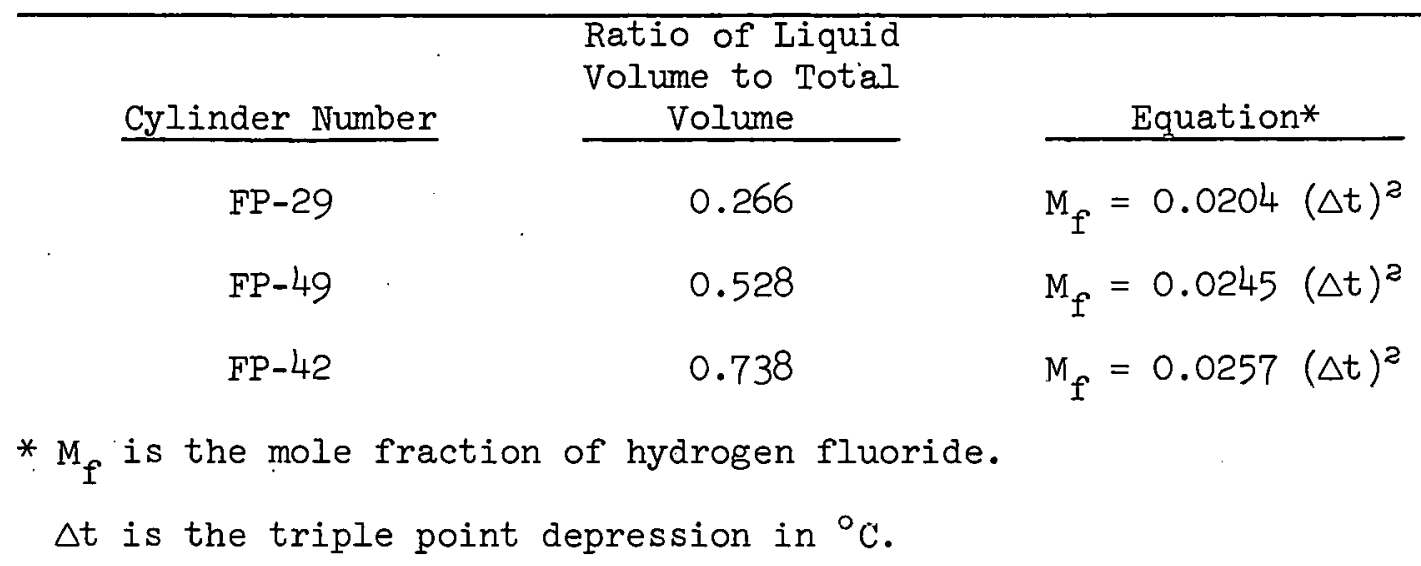

\section{Discussion}

The tungsten hexafluoride-hydrogen fluoride binary system does not form an ideal solution. The differences between the curves in figure 5 represent the magnitude of the non-ideality. To determine the molal triple point constant for tungsten hexafluoride, the curves of figure 5, each representing a different ratio of liquid volume to total volume, need be extrapolated to a curve representing a cell containing all liquid with no vapor volume. The extrapolated curve would be represented by a curve at the ratio of liquid volume to total volume of one $(R=1)$.

Using the ratios and equations of the three different cells from Table II, the mole fraction of hydrogen fluoride was expressed as a function of lhe triple point dcpression and the ratio of liquid volume to total volume. The following equation represents this function:

$$
M_{f}=(\Delta t)^{2} e^{\left(a+b R+c R^{2}\right)}
$$

where $M_{f}$ is the mole fraction of hydrogen fluoride in

$\Delta t$ is the triple point depression of tungsten hexafluoride

$R$ is the ratio of liquid volume to total volume

$a, b$, and $c$ are constants with the values
ค. $=-4.15$
$\mathrm{b}=1.11$
$c=-0.61$ 
DUG. NO. G-67-152

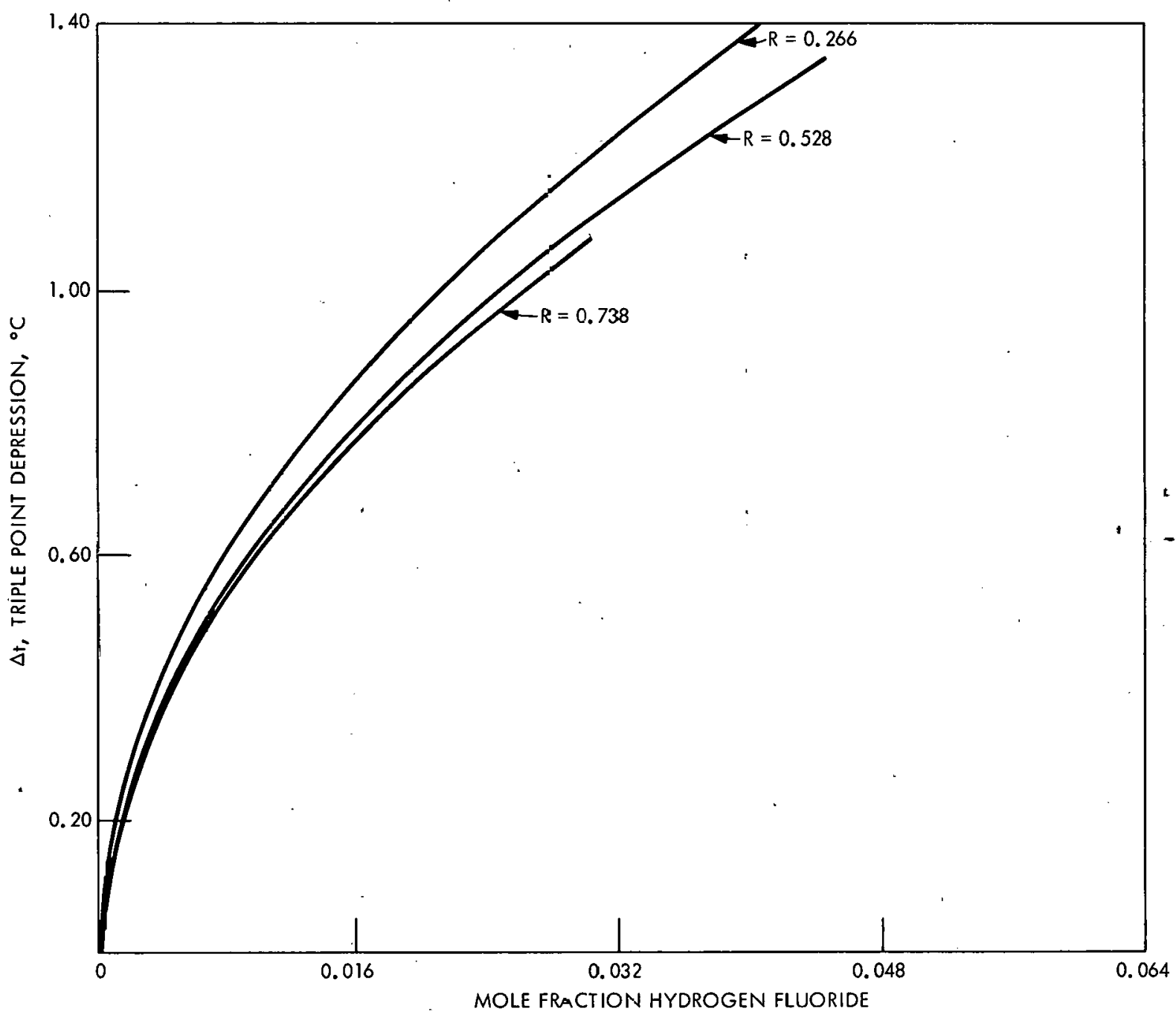

Figure 5

HYDROGEN FLUORIDE-TUNGSTEN HEXAFLUORIDE TRIPLE POINT CURVES

$\rightarrow \rightarrow$

$-$

$\therefore \rightarrow$

$\therefore$ 
Table III presents values of $M_{f}$ at various combinations of $R$ and $\Delta t$. Figure 6 is a plot of the three curves determined empirically and the extrapolated curves at ratios of liquid volume to total volume values of one and zero. These latter curves were determined by substituting values of $\Delta t$ at $R=1$ and $R=0$ in equation 3. The following equations were thus obtained:

$$
\begin{array}{ll}
R=1 & M_{f}=(\Delta t)^{2} e^{-3.65} \\
R=0 & M_{f}=(\Delta t)^{2} e^{-4.15}
\end{array}
$$

Application to a Method of Analysis

From the position of the curves in figure 6 , it is indicated that the vapor phase is relatively richer in. solvent than the liquid phase. Thus to obtain the gross composition of such a solution, the disparity between the liquid and vapor compositions must be considered. For example, in cryroscopic measurements the same triple point depression would yield a gross composition dependent upon the amount of solution present in a given cell; and in withdrawing liquid samples from such a solution, the samples would represent only the liquid composition. The normal analytical situation usually involves gross compositions, and the triple point curves form a base for estimating gross compositions.

A cell with a total volume of $225 \mathrm{ml}$, and containing 298 grams of tungsten hexafluoride and 0.2 grams of hydrogen fluoride, has a triple point depression of $0.66^{\circ} \mathrm{C}$. The ratio of liquid volume to total volume is

$$
R=\frac{G}{d V}
$$

where $R$ is the ratio of liquid volume to total volume

$G$ is the grams of solution

d is the density of solution

$\mathrm{V}$ is the total volume of the container. .

Thus for the system described above,

$$
R=298 /(3.518)(225)=0.38
$$

assuming the solute does not alter the density of the solvent.

The dashed lines in figure $7 \mathrm{~A}$ represent this solution. The dashed horizontal line from $\Delta t=0.66^{\circ} \mathrm{C}$ represents the triple point depression of the solution. The intersection of this horizontal line with the curve of $R=1.0$ is the liquid composition: 0.0113 mole fraction of hydrogen fluoride. The intersection with the curve $R=0.38$ is the gross composition: 0.0099. The intersection with the curve $R=0.0$ is the vapor composition: 0.0069 . 
TABLE III

MOLE FRACTION HYDROGEN FLUORIDE AT DIFFERENT RATIOS OF LIQUID VOLUME TO TOTAL VOLUME

\begin{tabular}{|c|c|c|c|c|c|c|c|}
\hline \multirow[b]{2}{*}{ Triple } & \multirow[b]{2}{*}{ Point Depression, ${ }^{\circ} \mathrm{C}$} & \multicolumn{6}{|c|}{ Ratio of Iiquid Volume to Total Volume } \\
\hline & & 1.0 & 0.8 & 0.6 & 0.4 & 0.2 & 0.0 \\
\hline & 0.0 & 0.0000 & 0.0000 & 0.0000 & 0.0000 & 0.0000 & 0.0000 \\
\hline & 0.1 & 0.0003 & 0.0003 & 0.0002 & 0.0002 & 0.0002 & 0.0001 \\
\hline & 0.2 & 0.0010 & 0.0010 & 0.0010 & 0.0009 & 0.0008 & 0.0006 \\
\hline & 0.3 & 0.0024 & 0.0023 & 0.0022 & 0.0020 & 0.0018 & 0.0014 \\
\hline & 0.4 & 0.0042 & 0.0042 & 0.0039 & 0.0036 & 0.0032 & 0.0025 \\
\hline & 0.5 & 0.0066 & 0.0065 & 0.0062 & 0.0056 & 0.0049 & $0.0040^{\circ}$ \\
\hline & 0.6 & 0.0094 & 0.0094 & 0.0089 & $\therefore 0.0080$ & 0.0071 & 0.0057 \\
\hline & 0.7 & 0.0128 & 0.0127 & 0.0121 & 0.0101 & 0.0096 & 0.0077 \\
\hline & 0.8 & 0.0168 & 0.0166 & 0.0158 & 0.0143 & 0.0126 & 0.0101 \\
\hline & 0.9 & 0.0212 & 0.0210 & 0.0199 & 0.0180 & 0.0159 & 0.0128 \\
\hline & 1.0 & 0.0262 & 0.0260 & 0.0246 & 0.0223 & 0.0196 & 0.0158 \\
\hline & 1.1 & 0.0317 & 0.0315 & 0.0298 & 0.0270 & 0.0238 & 0.0191 \\
\hline & 1.2 & 0.0377 & 0.0375 & 0.0355 & 0.0322 & 0.0283 & 0.0228 \\
\hline & 1.3 & 0.0443 & 0.0440 & 0.0416 & 0.0378 & 0.0333 & 0.0267 \\
\hline & 1.4 & 0.0514 & 0.0510 & 0.0483 & 0.0438 & 0.0386 & 0.0310 \\
\hline & 1.5 & 0.0590 & 0.0585 & 0.0554 & 0.0503 & 0.0443 & 0.0356 \\
\hline & 1.6 & 0.0671 & 0.0666 & 0.0630 & 0.0572 & 0.0504 & 0.0405 \\
\hline & 1.7 & --- & --- & --- & 0.0646 & 0.0569 & 0.0457 \\
\hline & 1.8 & -- & $\therefore-$ & --- & --- & 0.0638 & 0.0512 \\
\hline & 1.9 & -- & --- & -- & --- & --- & 0.0570 \\
\hline & 2.0 & --- & -- & --- & --- & $\cdots$ & 0.0632 \\
\hline
\end{tabular}


DWG. NO. G-67-153

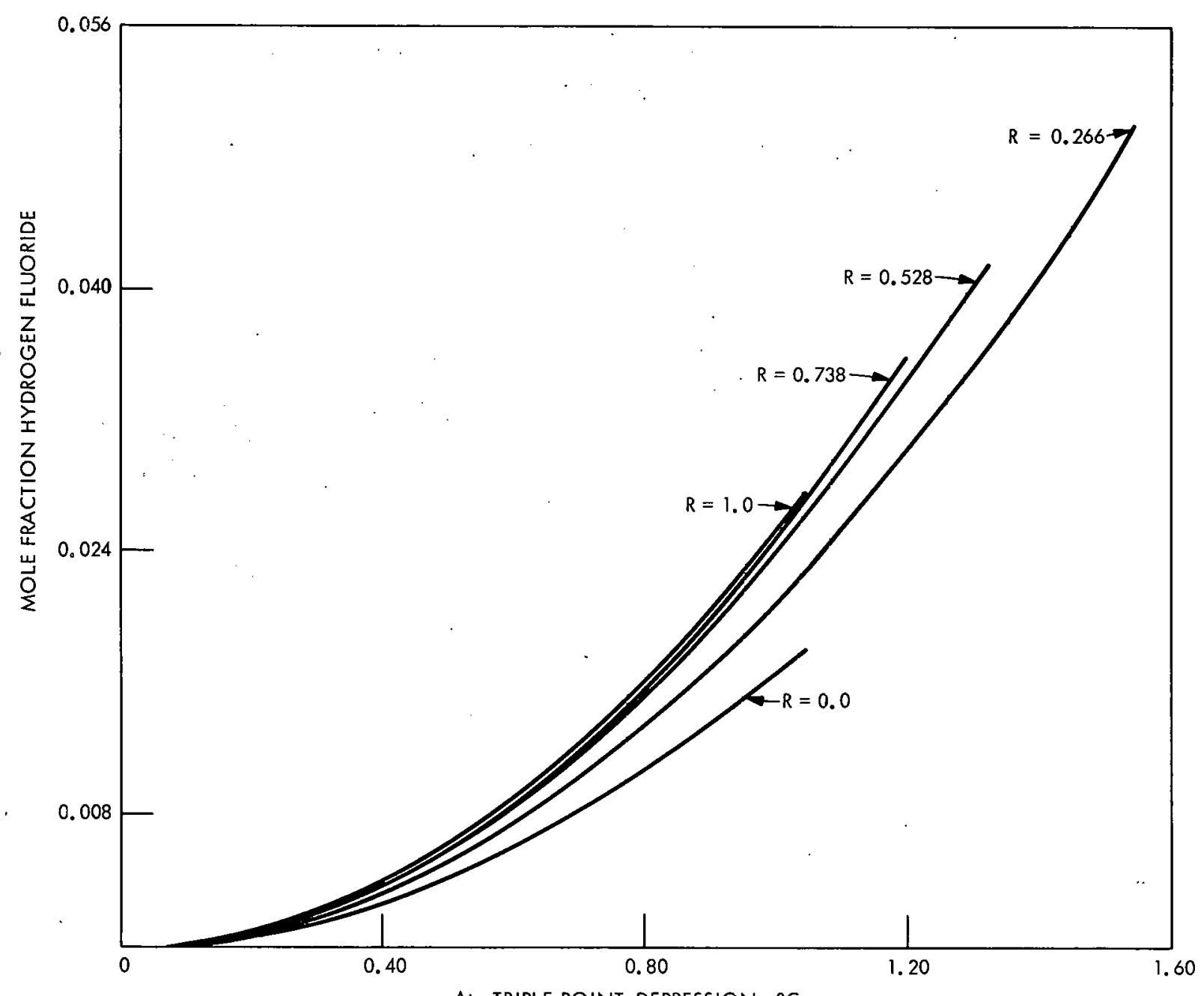

Figure 6

HYDROGEN FLUORIDE-TUNGSTEN HEXAFLUORIDE TRIPLE POINT SYSTEM CURVES 


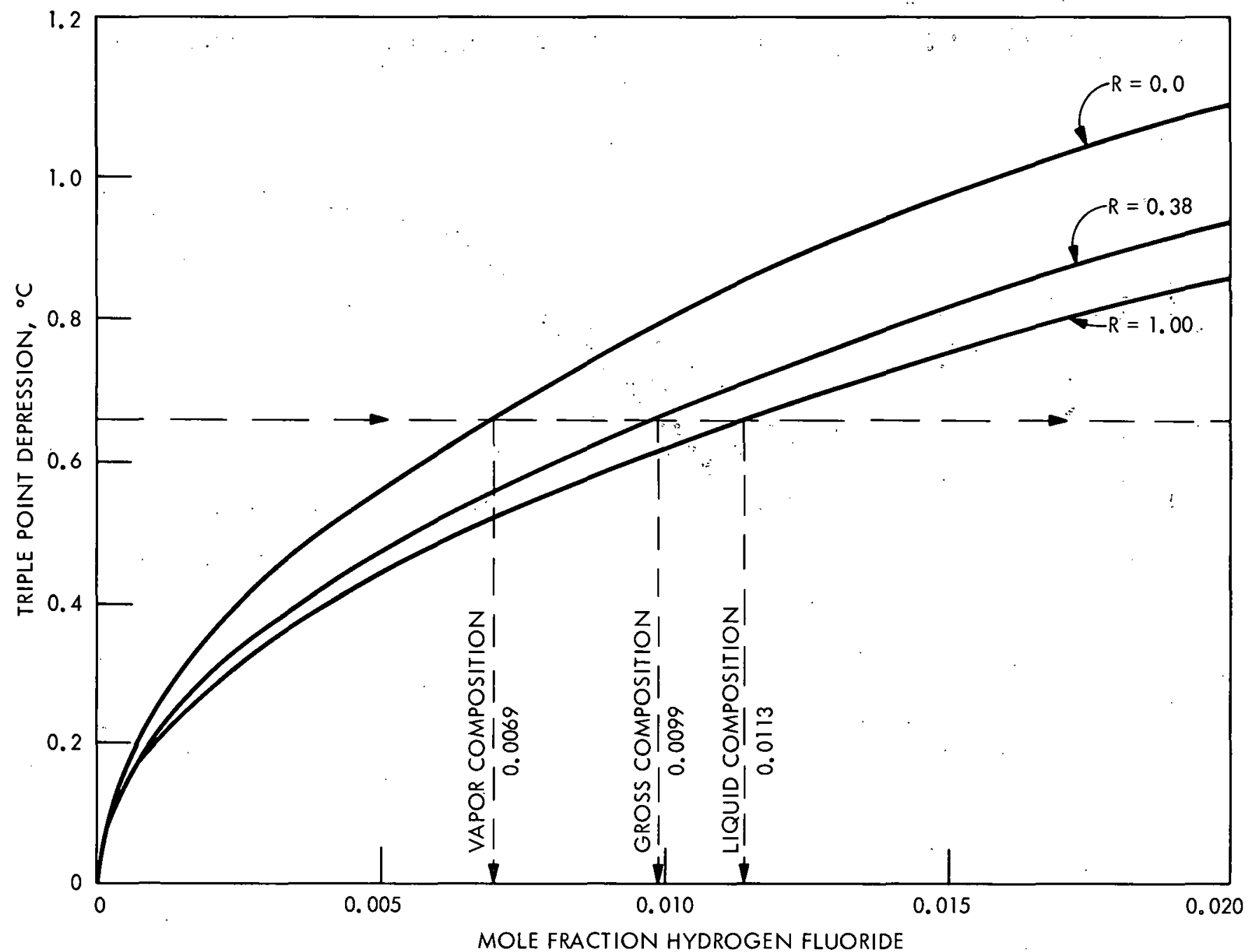

Figure 7A

GROSS, VAPOR, AND LIQUID COMPOSITION OF THE SYSTEM WF $6^{-H F}$ 
If such a system as described above were liquid-sampled and gravimetrically analyzed for mole fraction of tungsten, the result would represent the liquid phase only. Since material was withdrawn at the liquid composition, the gross composition remaining in the container after sampling is now different, and the composition of the liquid and vapor phase readjust to the new conditions.

To estimate the change resulting in the gross, liquid, and vapor compositions due to withdrawing a liquid portion of the solution, assume that 100 grams of liquid were withdrawn from the solution represented by the dashed lines in figure 7A. Thus the container now has 198 grams of solution with a ratio of liquid to total volume of $198 /(3.518)(225)=0.25$. To detarmine the gross, liquid, and vapor compositions of the remaining solution after the withdrawal, generate a line parallel to the triple point depression axis from the intersection $(\Delta t=0.66, R=0.25)$ to the intersection with $\mathrm{R}=0.38$. From this latter intersection, generate a line parallel to the mole fraction axis. The intersection of this latter line with the curve $R=1.0$ is the liquid composition: 0.0101 mole fraction hydrogen fluoride. The intersection with the curve $R=0.25$ is the gross composition: 0.0077 mole fraction. And the intersection with the curve $R=0.0$ is the vapor composition: 0.0061 mole fraction. This procedure is illustrated in figure 7B. Identical results may be obtained by determining the triple point depression after withdrawing the sample (estimated graphically in figure $7 \mathrm{~A}$ by $\wedge t=0.62$ ). After determining the triple point depression, Equation 2 may be used to solve for the desired compositions.

Figure 8 is a graphic presentation of the expected gross, liquid, and vapor compositions of a typical tungsten hexafluoride-hydrogen fluoride binary solution. Note that when the ratio of liquid volume to total volume equals one (all liquid), the gross and liquid compositions are equal. When the ratio of liquid volume to total volume equals zero (all vapor), the gross and vapor compositions are equal.

\section{ACKINOWLEDGEMENTS}

The author wishes to acknowledge Mr. R. J. Wertz for his many suggestions and general guidance in the course of this study, and Miss Jane Howell for her treatment of the data on the IBM 7090 computer.

\section{BIBLIOGRAPHY}

1. Ryss, I. G., The Chemistry of Fluorine and Its Inorganic Compounds, United States Atomic Energy Commission, 1960, p 734 (AEC-tr-3927, part 2) (Unclassified).

2. Hargreaves, G. B. and Cody, G., "The Vapor Pressures of Some Heavy Transition Metal Fluorides," J. Amer. Chem. Soc., No. 305 (April 1961), pp 1563-74e. 


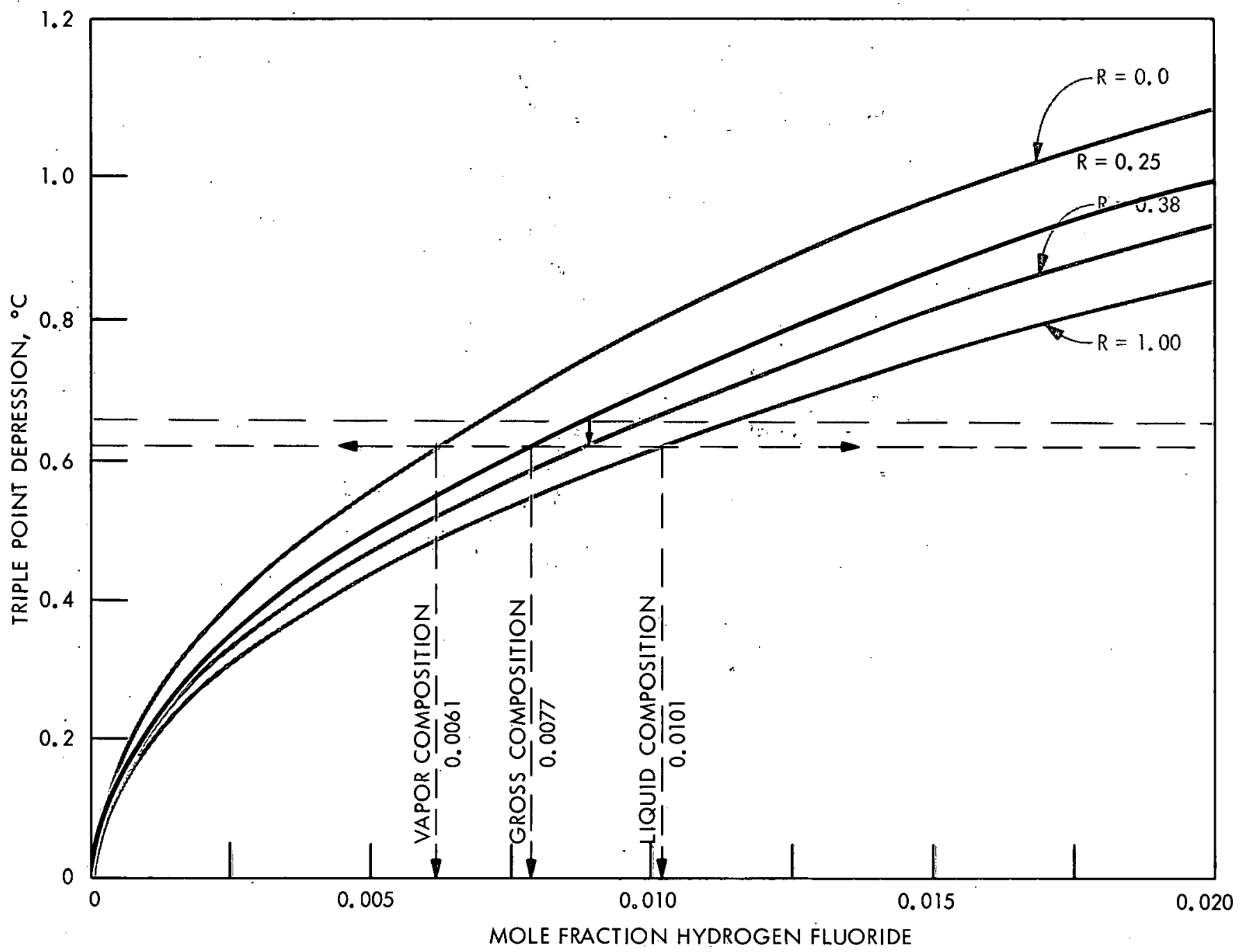

Figure 7B

GROSS, VAPOR, AND LIQUID COMPOSITION OF THE SYSTEM WF 6 -HF 
DWG. NO. G-67-156

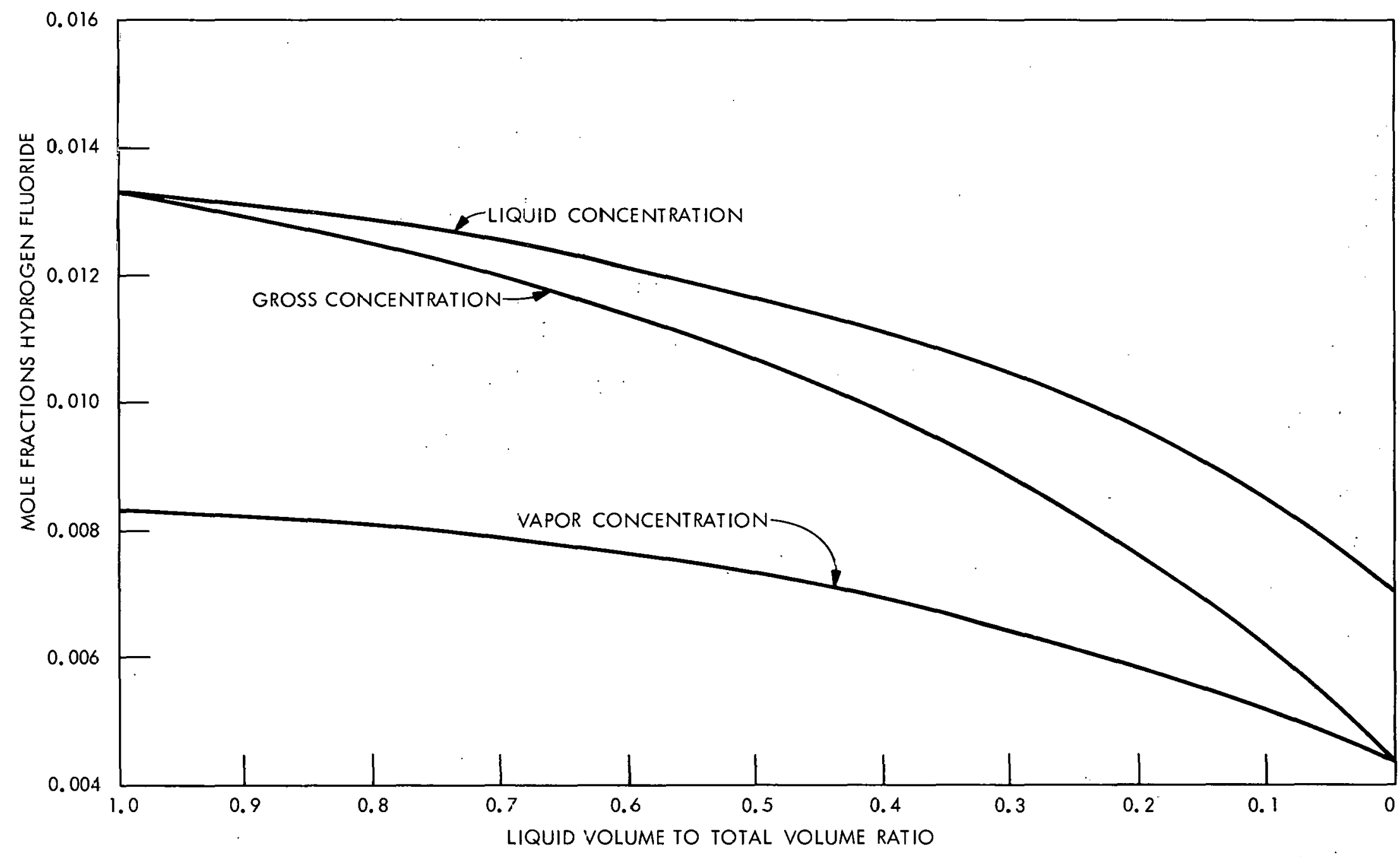

Figure 8

MOLE FRACTION HYDROGEN FLUORIDE DISTRIBUTION FOR

A TYPICAL WF 6 -HF SOLUTION 
3. Hedge, W. D., The Molal Freezing Point Depression Curve of Uranium Hexafluoride and Its Application to a Method of Analysis, Union Carbide Corporation, Nuclear Division, Oak Ridge Gaseous Diffusion Plant, January i7., 1967 (K-1677) (Unclassified). 